\title{
GLOBAL MIGRATION, ENTREPRENEURSHIP AND SOCIETY
}




\section{CONTEMPORARY ISSUES IN ENTREPRENEURSHIP RESEARCH}

\section{Series Editor, Volumes 1-6: Gerard McElwee}

Volume 7 onward: Paul Jones

Volume 1: Innovating Women: Contributions to Technological Advancement Edited by Pooran Wynarczyk and Susan Marlow

Volume 2: $\quad$ Social and Sustainable Enterprise: Changing the Nature of Business Edited by Sarah Underwood, Richard Blundel, Fergus Lyon and AnjaSchaefer

Volume 3: $\quad$ Enterprising Places: Leadership and Governance Edited by Lee Pugalis and Joyce Liddle

Volume 4: $\quad$ Exploring Rural Enterprise: New Perspectives on Research, Policy and Practice

Edited by Colette Henry and Gerard McElwee

Volume 5: Exploring Criminal and Illegal Enterprise: New Perspectives on Research, Policy and Practice

Edited by Gerard McElwee and Robert Smith

Volume 6: New Perspectives on Research, Policy and Practice in Public Entrepreneurship

Edited by Joyce Liddle

Volume 7: New Perspectives on Entrepreneurship Education

Edited by Paul Jones, Gideon Maas and Luke Pittaway

Volume 8: Entrepreneurship and the Sustainable Development Goals

Edited by Nikolaos Apostolpoulos, Haya Al-Dajani, Diane Holt, Paul Jones and Robert Newbery

Volume 9a: Creating Entrepreneurial Space: Talking Through Multi-voices, Reflections on Emerging Debates

Edited by David Higgins, Paul Jones and Pauric McGowan

Volume 9B: Creating Entrepreneurial Space: Talking Through Multi-voices, Reflections on Emerging Debates

Edited by David Higgins, Paul Jones and Pauric McGowan

Volume 10: International Entrepreneurship in Emerging Markets: Nature, Drivers, Barriers and Determinants

Edited by Mohamed Yacine Haddoud, Paul Jones and Adah-Kole Emmanuel Onjewu

Volume 11: Universities and Entrepreneurship: Meeting the Educational and Social Challenges

Edited by Paul Jones, Nikolaos Apostolopoulos, Alexandros Kakouris, Christopher Moon, Vanessa Ratten and Andreas Walmsley

Volume 12: Entrepreneurship in Policing and Criminal Contexts Edited by Robert Smith

Volume 13: Global Migration, Entrepreneurship and Society

Edited by Natalia Vershinina, Peter Rodgers, Mirela Xheneti, Jan Brzozowski and Paul Lasalle 


\title{
GLOBAL MIGRATION, ENTREPRENEURSHIP AND SOCIETY
}

\author{
EDITED BY \\ NATALIA VERSHININA \\ Audencia Business School, France \\ PETER RODGERS \\ University of Southampton, UK \\ MIRELA XHENETI \\ University of Sussex, UK

\section{JAN BRZOZOWSKI}

Cracow University of Economics, Poland

and

\section{PAUL LASSALLE}

University of Strathclyde, Scotland

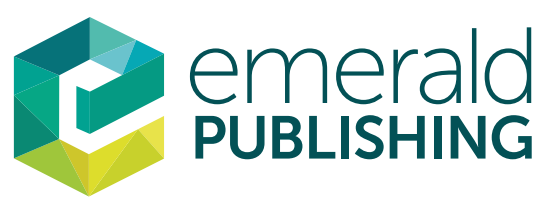

United Kingdom - North America - Japan India - Malaysia - China 
Emerald Publishing Limited

Howard House, Wagon Lane, Bingley BD16 1WA, UK

First edition 2021

Copyright (C) 2021 Emerald Publishing Limited

Reprints and permissions service

Contact: permissions@emeraldinsight.com

No part of this book may be reproduced, stored in a retrieval system, transmitted in any form or by any means electronic, mechanical, photocopying, recording or otherwise without either the prior written permission of the publisher or a licence permitting restricted copying issued in the UK by The Copyright Licensing Agency and in the USA by The Copyright Clearance Center. Any opinions expressed in the chapters are those of the authors. Whilst Emerald makes every effort to ensure the quality and accuracy of its content, Emerald makes no representation implied or otherwise, as to the chapters' suitability and application and disclaims any warranties, express or implied, to their use.

British Library Cataloguing in Publication Data

A catalogue record for this book is available from the British Library

ISBN: 978-1-83982-097-7 (Print)

ISBN: 978-1-83982-096-0 (Online)

ISBN: 978-1-83982-098-4 (Epub)

ISSN: 2040-7246 (Series)

ISOQAR certified

Management System,

awarded to Emerald

for adherence to

Environmental

standard

ISOQAR ISO 14001:2004. 


\section{CONTENTS}

Author Biographies

Chapter 1 Global Migration, Entrepreneurship and Society: Setting the New Research Agenda

Natalia Vershinina, Peter Rodgers, Mirela Xheneti, Jan Brzozowski and Paul Lassalle

\section{SECTION I: CONTEMPORARY ISSUES}

Chapter 2 Entrepreneurial Edge in the Age of Migration: Systematic Review of Migrant Entrepreneurship Literature Tatiana Egorova

Chapter 3 What Do We Talk About When We Talk About Ethnic Entrepreneurship?

Tayo Korede

Chapter 4 Cosmopolitans as Migrant Entrepreneurs

Niina Nummela, Eriikka Paavilainen-Mäntymäki, Riikka Harikkala-Laihinen and Johanna Raitis

Chapter 5 Migrant Enterprises: Diversity and Emotions at Work

Kiran Trehan, Rachel Hu and Alex Kevill

Chapter 6 Underdog Refugee Entrepreneurs and the Challenge-based Model of Entrepreneurship

Sibylle Heilbrunn

\section{SECTION II: BOUNDARIES AND BEYOND}

Chapter 7 The Dynamic Nature of Transnational Entrepreneurship Among Albanian Migrants and Returnees Joniada Barjaba 
Chapter 8 Transnational Symbolic Capital and the Business Accelerator

Alia Noor

Chapter 9 Multicultural Hybridism as a Dynamic

Framework to Reconceptualise Breakout in a Superdiverse and Transnational Context

Xiping Shinnie, Thomas Domboka and Charlotte Carey

Chapter 10 Networks and Migrant Entrepreneurship:

Ukrainian Entrepreneurs in Poland

Michat Borkowski, Jan Brzozowski, Natalia Vershinina and

Peter Rodgers

Chapter 11 Mexicans in Quebec: When the Context

Matters in Immigrant Entrepreneurship

Héctor José Martínez Arboleya

Chapter 12 Notions and Practices of Differences: An Epilogue on the Diversity of Entrepreneurship and Migration Sakura Yamamura and Paul Lassalle 


\section{AUTHOR BIOGRAPHIES}

Dr Joniada Barjaba completed her PhD studies at the University of Sussex, School of Global Studies. She has a special interest in ethnic entrepreneurship and small business development in developing countries. She has Bachelor of Arts degrees in Economics and Sociology from Emory University (2011). She also holds a Master's degree in International Policy Studies from Stanford University (2013). Prior to joining Sussex, she worked as a Research Assistant at Stanford Graduate School of Business. She has worked on different projects that explore the migration-development nexus and has conducted both qualitative and quantitative research. She currently serves as Director of European Integration at the Ministry of Finance and Economy in Albania.

Michał Borkowski is an Independent Researcher and MA student at the University College London (School of Slavonic and East European Studies). He has worked as a Research Assistant in the Multicultural and Migration Observatory at Cracow University of Economics.

Dr Jan Brzozowski holds a PhD in Economics and works as Associate Professor at Cracow University of Economics (CUE). He is a Deputy-Director of Center for Advanced Studies of Population and Religion at CUE and a member of the Committee for Migration Research and Committee for Demography at Polish Academy of Sciences. His research interests include migrant entrepreneurship, international migration and development and immigrant's socio-economic integration.

Dr Charlotte Carey has worked as a Researcher and now Senior Lecturer within the Department of Strategy, Applied Management and Marketing at Birmingham City University Business School, with a creative background, focussing on entrepreneurship within the creative industries and entrepreneurship education. She leads the Entrepreneurship Research Cluster at Birmingham City University Business School. She also co-chairs the Creative Industries track, Institute of Small Business and Entrepreneurship.

Dr Thomas Domboka is an Associate Professor at Birmingham City University where he also teaches Entrepreneurship and Innovation to postgraduate students as well as supervising several $\mathrm{PhD}$ students. He has particular research interests in ethnic and minority entrepreneurship that broadly encompasses Black, Asian Minority Ethnic groups including migrants and refugees. He also has research 
interests in gender and entrepreneurship. He is a member of the Institute of Small Business Entrepreneurship, where he currently chairs the entrepreneurship in minority groups' conference track and is a founder member of a Special Interest Group on entrepreneurship in minority groups that is affiliated to the conference track he chairs. Besides his entrepreneurship research background, he comes from a practitioner background, having been an entrepreneur himself and a management consultant. He has been involved with several start-ups and has worked in senior management roles in various organisations in the UK and abroad.

Tatiana Egorova is a $\mathrm{PhD}$ candidate at the House of Innovation at Stockholm School of Economics. Her research centres around entrepreneurship, with a particular focus on immigrant and social entrepreneurs. Her current research project is focussed on the comprehensive assessment of the well-being of immigrant entrepreneurs. She is also involved in teaching several master-level courses on sustainability, leadership, and innovation. She is a former serial entrepreneur and management consultant.

Dr Riikka Harikkala-Laihinen is a Postdoctoral Researcher in International Business at the Turku School of Economics at the University of Turku, Finland. Her areas of expertise include emotions in organisations, cross-border acquisitions and cross-cultural management. Her current work centres on exploring the influence of employee emotions at work at the employee, entrepreneurial and managerial levels. Her work has been published, for example, in the Research on Emotion in Organizations book series, International Small Business Journal and Cross-Cultural \& Strategic Management.

Dr Sibylle Heilbrunn is Dean of the Faculty of Social Sciences and Humanities at the Kinneret Academic College on the Sea of Galilee. She is an organisational sociologist, specialising at the intersection of migration, minorities and entrepreneurship. She held a Visiting Professorship at Bremen University and the International School of Management in Dortmund. She is on editorial boards of leading entrepreneurship and management journals such as Journal of Entrepreneurial Behaviour and Research and European Journal of International Business. Lately she has published several articles and chapters on refugee entrepreneurship focussing on African asylum seekers and refugees, gender and bricolage. Together with colleagues, she edited a book called Refugee Entrepreneurship: A Case-based Topography which was published in 2018 by Palgrave MacMillan.

Rachel Hue worked as a Research Fellow at the University of Birmingham between 2014 and 2018, getting involved in a multi-sited sociolinguistic project funded by the UK Arts and Humanities Research Council. She is working on her PhD study of the everyday entrepreneurship and transnational identities negotiation among the Chinese migrants owning SMEs and transnational start-ups in the UK. She is interested in studying transnational and immigrant entrepreneurship. 
Dr Alex Kevill is a Lecturer in Enterprise and Entrepreneurship in the Centre for Enterprise and Entrepreneurship Studies at the University of Leeds. His research interests include dynamic capabilities, micro-enterprises and entrepreneurial well-being.

Tayo Korede holds a $\mathrm{PhD}$ in Management and Entrepreneurship from Newcastle University. He is a lecturer in Management and Entrepreneurship at the University of Central Lancashire UCLan. His research interest focuses on entrepreneurship, work and identity.

Dr Paul Lassalle is a Lecturer at the Hunter Centre for Entrepreneurship, University of Strathclyde. He studied Sociology and Political Sciences at Sciences Po Paris and is conducting research on societal issues of diversity and migration in entrepreneurship. He publishes in both leading entrepreneurship and migration journals, such as Entrepreneurship Theory \& Practice and the Journal of Ethnic and Migration Studies. His most recent publications include works on intersectionality in entrepreneurship, as well as research on superdiversity in Glasgow and on migrant entrepreneurs' diversification strategies. For his research engagements, he also collaborates with the Scottish Government and with institutions supporting migrant entrepreneurs in the establishment and the development of their new venture.

Dr Héctor José Martínez Arboleya is a Full-Time Professor in the International Business Programme at the Autonomous University of Chihuahua in Hidalgo del Parral, México. He holds a PhD in Geography from Laval Universty in Quebec, Canada.

Alia Noor is an Independent Researcher. Her main research interests lie in studying the human side of entrepreneurship.

Dr Niina Nummela is a Professor of International Business at the Turku School of Economics, University of Turku, Finland. Her areas of expertise include international entrepreneurship, cross-border acquisitions and research methods. She has published widely in academic journals and contributed to several internationally published books, also as an editor. In a recent bibliometric analysis, she was ranked among the 30 most impactful scholars in the field of International Entrepreneurship. Her current research interests revolve around cosmopolitan individuals, international opportunity recognition and mixed-methods as research strategy.

Dr Eriikka Paavilainen-Mäntymäki is an Associate Professor in International Business at the University of Turku, Finland and an Adjunct Professor at the University of Vaasa, Finland. Her research interests focus on the internationalisation processes of firms, entrepreneurship in small- and medium-sized and family enterprises, the role of time in research and qualitative research methods. She 
is a member of the Journal of International Business Studies Editorial Review Board. She has published and reviewed articles in several journals, and edited a handbook on longitudinal research methods (Edward Elgar) and a special issue on time in international business research (Journal of World Business).

Dr Johanna Raitis is a Postdoctoral Researcher in International Business and a TIAS Research Fellow at the University of Turku, Finland. Her research interests lie in culture, identity, values and socio-cultural integration. She has an extensive experience in conducting qualitative, cross-cultural research in collaboration with multinational corporations. She has edited a book on socio-cultural integration in mergers and acquisitions (Palgrave Macmillan) and published in various academic journals, most recently in Journal of Management Studies.

Dr Peter Rodgers is a Professor in Strategy and International Management and MBA Director at Southampton Business School, University of Southampton. His research centres on informality within state-business relations, corruption and non-market strategies.

Xiping Shinnie is a $\mathrm{PhD}$ researcher from Birmingham City University Business School. Her PhD research focusses on the breakout of Chinese migrant entrepreneurs in Birmingham. She is a Committee Member of the Entrepreneurship in Minority Groups Special Interest Group, Institute of Small Business and Entrepreneurship. She also teaches undergraduate and postgraduate students at the University of Birmingham.

Dr Kiran Trehan is Pro-Vice Chancellor for Partnerships and Engagement at The University of York and Director of the Centre for Women's Enterprise, Leadership, Economy \& Diversity. She is a key contributor to debates on leadership, enterprise development and diversity in small firms and business. She has led a number of leaderships, enterprise and business support initiatives and has extensively published a number of journal articles, policy reports, books and book chapters in the field. Her work has been supported by grants from a full range of research funding bodies, including the Economic and Social Research Councils and Arts Humanities Research councils, government departments, regional and local agencies including Local Enterprise Partnerships and Chambers of Commerce and the private sector. She has held a number of national and international advisory roles that shape debates and policy in diversity and enterprise. She has led on a number of public and private services initiatives in the area of transformation, leadership and diversity

Dr Natalia Vershinina is a Professor of Entrepreneurship, and Head of Research for Business and Society Department at Audencia Business School in Nantes, France. She has previously worked for De Montfort University and University of Birmingham in the UK. She currently serves as an Associate Editor of Entrepreneurship \& Regional Development Journal, and International Journal 
of Entrepreneurship and Business Research. In her work Natalia has researched how entrepreneurship intersects with ethnicity, gender and family business contexts and her latest publications examine motherhood, impact of online communities for development of confidence and legitimacy amongst women, and transitions to self-employment and entrepreneurship of women in couples.

Dr Mirela Xheneti is a Senior Lecturer in Entrepreneurship and Small Business and the Head of Engagement for the Strategy \& Marketing Department at the University of Sussex Business School. She has a long-standing interest in how institutional change and enterprise policies affect entrepreneurial behaviour placing particular emphasis on the role of context. Her most recent work looks at the intersection of the informal economy and gender in developing country contexts. She currently serves on the Board of Directors of the European Council for Small Business and Entrepreneurship. Her work has appeared in numerous journal articles including Journal of Business Ethics, Entrepreneurship and Regional Development Journal, Strategic Entrepreneurship Journal, International Journal of Management Reviews and Environment and Planning C-Government and Policy.

Dr Sakura Yamamura is Postdoctoral Researcher at the Max Planck Institute for the Study of Religious and Ethnic Diversity. With expertise in migration studies, urban and economic geography, her work focusses on the spatiality of social and economic activities in migrant-led diversification of society, particularly in cities. She studied Geography, Sociology and Social/Cultural Anthropology at the University of Hamburg, Université de Paris 1 - Sorbonne and the University of California Berkeley. Previously working for the OECD International Migration Division and the German Federal Office for Migration and Refugees, she also taught at Geography Departments in Hamburg and Kiel. Her research results have been published by leading journals, such as Journal of Ethnic and Migration Studies, and as a monograph in Palgrave Macmillan, with contributions in seminal volumes, such as the Handbook on Superdiversity published by Oxford University Press. 
This page intentionally left blank 


\section{LIST OF CONTRIBUTORS}

\author{
Joniada Barjaba \\ Michat Borkowski \\ Jan Brzozowski \\ Charlotte Carey \\ Thomas Domboka \\ Tatiana Egorova \\ Riikka Harikkala-Laihinen \\ Sibylle Heilbrunn
}

Rachel Hue

Alex Kevill

Tayo Korede

Paul Lassalle

Héctor José Martínez Arboleya

Alia Noor

Niina Nummela

Eriikka Paavilainen-Mäntymäki

Johanna Raitis

Peter Rodgers

Xiping Shinnie

Kiran Trehan

Natalia Vershinina

Mirela Xheneti

Sakura Yamamura
Ministry of Finance and Economy, Albania

Cracow University of Economics, Poland

Cracow University of Economics, Poland

Birmingham City University, UK

Birmingham City University, UK

House of Innovation at Stockholm, Sweden

University of Turku, Finland

Kinneret Academic College on the Sea of Galilee, Isreal

University of Birmingham, UK

University of Leeds, UK

University of Central Lancashire, UK

University of Strathclyde, UK

Autonomous University of Chihuahua in Hidalgo del Parral, México

Research conducted at the University of Sussex, UK

University of Turku, Finland

University of Turku, Finland and University of Vaasa, Finland

University of Turku, Finland

University of Southampton, UK

Birmingham City University, UK

The University of York, UK

Audencia Business School, France

University of Sussex, UK

Max Planck Institute for the Study of Religious and Ethnic Diversity, Germany 
This page intentionally left blank 


\title{
CHAPTER 1
}

\section{GLOBAL MIGRATION, ENTREPRENEURSHIP AND SOCIETY: SETTING THE NEW RESEARCH AGENDA}

\author{
Natalia Vershinina, Peter Rodgers, Mirela Xheneti, \\ Jan Brzozowski and Paul Lassalle
}

Society forms the individuals who create society, forming a continuous loop. (Giddens, 1984)

This book aims to explore the interconnected processes of global migration and entrepreneurship. Whilst in recent years there has been much focus on the political dimensions of migration around the world, there has been less attention given to the critical role that entrepreneurship can play in facilitating economic and social integration of migrants in new host societies. Global trends in migration stress the role played by increasing flows of movement of people and capital. These movements have led to variations in entrepreneurship practices too. A closer look at the different social, cultural and political contexts can not only reveal different processes of integration, but also the critical influence the narratives and discourses of 'othering' plays around the nexus of migration and entrepreneurship. Academically, this calls for a scan of the different scholarly contributions on the entrepreneurial endeavours of migrants in an era of diversification. It also calls for theoretical and methodological advancements in the study of heterogeneous and diverse forms of migrant entrepreneurship, challenging the existing methodologies and knowledge, as well as proposing alternative approaches and lenses to analyse such a topical phenomenon.

Within this book, we present contributions, which take into account the relevance of social and cultural contexts (Bruton, Ahlstrom, \& Li, 2010; Welter \&

Global Migration, Entrepreneurship and Society

Contemporary Issues in Entrepreneurship Research, Volume 13, 1-7

Copyright (C) 2021 by Emerald Publishing Limited

All rights of reproduction in any form reserved

ISSN: 2040-7246/doi:10.1108/S2040-724620210000013001 
Smallbone, 2006) for understanding manifestations of migrant entrepreneurship by focussing at both macro- and micro-levels of analysis. We present scholarly work, which zoom in on the 'everyday' nature of varied manifestations of entrepreneurial practices, rather than simply accepting the traditional view of entrepreneurial activities involving the 'super-hero' stereotype of the entrepreneur (Burns, 2001). Some of the contributions that are being published in this volume are aligned to the growing strand of literature on critical entrepreneurship (Anderson, Dodd, \& Jack, 2010), which call for the recognition of the everyday (Johannisson, 2011; Welter, Baker, Audretsch, \& Gartner, 2017) and mundane nature (Rehn \& Taalas, 2004) of varied forms of entrepreneurship. Embracing the desire within the 'European tradition' of entrepreneurship (Down, 2013; Gartner, 2013; McKeever, Anderson, \& Jack, 2014) to look beyond the 'mainstream' has led to scholarly enquiry into the 'other' entrepreneurial individuals (Gartner, 2013) and into the practices of living taking place on the edges and margins of our societies (Imas, Wilson, \& Weston, 2012; Vershinina, Rodgers, McAdam, \& Clinton, 2019; Watson, 2013).

Traditional approaches to ethnic entrepreneurship portray individuals as members of the group with the same origin and culture (Aldrich \& Waldinger, 1990; Wilson \& Portes, 1980), usually operating in ethnic enclaves and serving their co-ethnic populations in an ethnic district. Alternatively, they play the role of middlemen minorities, implying the use of ethnic resources to secure economic exchange between host society representatives and their ethnic group, or, alternatively, their country of origin (Koning \& Verver, 2013). Consequently, these ethnic entrepreneurship perspectives are often perceived as limiting, as the individuals who pursued such business models had to accept fierce competition, small profit margins, long working hours and poor working conditions (Rath \& Kloosterman, 2000). For immigrants who wanted to expand their businesses further, losing the ethnic mark and breaking into the mainstream economy was considered as the best alternative (Zhou, 2004).

Since then, this traditional view has been challenged and complemented with novel approaches, which break with the ethno-focal lens of the traditional model of migrant and ethnic minority entrepreneurship. Following Vertovec's (2007) seminal work on superdiversity in London, entrepreneurship scholars have started to consider the wider diversity of backgrounds and contexts of migrant entrepreneurial activities (Ram, Theodorakopoulos, \& Jones, 2008; Syrett \& Sepulveda, 2011; Yamamura \& Lassalle, 2019). In addition, the rise of transnationalism has caught attention of migrant entrepreneurship scholars and provided a conceptual opportunity to analyse and understand the complexity and multiple layers of contexts, including movements and flows across borders (Brzozowski, Cucculelli, \& Surdej, 2017; Rodgers, Vershinina, Williams, \& Theodorakopoulos, 2019). Building on the work of Drori, Honig, and Wright (2009) and Portes, Guarnizo, and Haller (2002), transnational entrepreneurship research focusses on the embeddedness of migrant entrepreneurship in multiple contexts. Transnational entrepreneurship presents migrants as agents of change, becoming global entrepreneurs, and being able to become more competitive than native entrepreneurs who are focussed on domestic markets only (Brzozowski \& Cucculelli, 2020). However, research has also challenged the traditional assumption of middlemen 
and increasingly considered the diversification of the activities of the migrant entrepreneurs within such super-diverse contexts (Kloosterman, Rusinovic, \& Yeboah, 2016; Lassalle \& Scott, 2018).

The field of migrant entrepreneurship is open for novel theoretical lenses, borrowing from other social sciences for a finer-grained understanding of the activities of migrant entrepreneurs situated at the intersection of the diverse social structures constraining their entrepreneurship (Lassalle \& Shaw, 2021; Vershinina, Rodgers, Tarba, Khan, \& Stokes, 2020). In this respect, location and positionality or translocational positionality (Anthias, 2002) are becoming increasingly useful concepts for investigating migrant entrepreneurship specifically through the lens of processes and outcomes of collective identification. The translocational positionality of individuals influences their understanding of the broader social relations that constitute and are constituted in the process of identification (Villares-Varela \& Essers, 2019). Such understandings of migrant entrepreneurs have the potential to enhance our broader views of the influence of transnationalism and other contextual variables upon migrant entrepreneurship processes and practices. Within this 'age of super-diversity' (Ram, Jones, \& Villares-Varela, 2016; Vertovec, 2007), new migrant groups, engaged in either voluntary or involuntary forms of migration, are yet to be fully represented in contemporary debates on self-employment and/or entrepreneurship (Edwards, Ram, Jones, \& Doldor, 2016).

Whilst no volume is encompassing of all ongoing debates in the field of migrant entrepreneurship, this volume presents works that are diverse but nonetheless complementary, therefore adding to the body of knowledge on migrant entrepreneurship. Some of the chapter contributions are critical and they also pave the way for new topics and new research questions to be brought into the academic debates and conversations. We now move on to introducing our stellar authors and the scholarly work that they have contributed towards this volume.

The first section on 'Contemporary Issues' provides a critical overview of the current debates and theoretical advancements in the field of migrant entrepreneurship. The first five chapters both present and challenge current definitions and foci in the literature, their theoretical assumptions and the most accepted and common empirical grounding.

Firstly, in her review of the existing literature on migrant entrepreneurship, Tatiana Egorova highlights the need for clarifying definitions of the terms such as migrant, ethnic, transnational and diaspora and calls for clearer demarcations of the related factors in entrepreneurship. She further identifies the need to account for the multi-levelled nature of migrant entrepreneurship to appreciate the role of different factors influencing it. Based on this observation, she proposes that further studies should assess the boundary conditions and identify moderating and mediating effects, particularly at the micro- and meso-levels. She further suggests integrating the role played by new technologies in the study of migrant entrepreneurship.

Secondly, Olutayo Korede challenges the existing conceptualisations of what it means to be an ethnic entrepreneur by drawing on the new perspectives and new realities of the composition of contemporary and ever evolving societies. $\mathrm{He}$ posits specifically that the term 'ethnic entrepreneur' is discriminatory and the one responsible for creating 'othering' narrative in the entrepreneurship literature. 
The author proposes ways in which in the era of superdiversity and globalisation, researchers can re-think the conceptual boundaries of ethnic entrepreneurship and develop more inclusive views of migrant entrepreneurs.

Thirdly, in a study of cosmopolitan entrepreneurs in Finland, Niina Nummela and her co-authors explore how cosmopolitan disposition affects entrepreneurial behaviour. This chapter expands on conceptual boundaries of who migrant entrepreneurs are by focussing on this novel context. The authors identify openness, desire for freedom and self-fulfilment to be strong characteristics of cosmopolitan entrepreneurs. Being mobile and multilocal, they downplay the role of national affiliations and cultural differences. By bringing into focus the notion of cosmoscape, as the combination of spaces, practices, objects and networks facilitating cosmopolitan life, the authors draw attention to the specific behaviours of cosmopolitan entrepreneurs.

Fourthly, in an empirical investigation, Kiran Trehan and co-authors specifically uncover a set of transnational practices which are enacted as part of gendered and ethnicity-based strategies of Chinese migrant entrepreneurs. These practices are embedded in the context of austerity and are part of the regenerative action of migrant entrepreneurs and their businesses. Specifically, the authors examine the role of emotions in this process of small transnational enterprises learning to navigate the complex and turbulent terrain.

Finally, in this section, we have a contribution from Sibylle Heilbrunn, who focusses on refugee entrepreneurs and emancipatory discourses. Sibylle presents a study of 12 refugee entrepreneurs to examine the dynamics of challenges and adaptive mechanisms enacted by this group. She conceptualises these actions through the challenge-based model of entrepreneurship and presents ways in which highly marginalised individuals develop successful agentic responses to the situations they face that enable their social mobility.

In the next section of this volume on 'Boundaries and Beyond', we have included six contributions with a focus on the transnational nature of migrant entrepreneurship and its socio-economic impact at both the individual and country levels. These chapters highlight the transnational nature of the opportunity structure by focussing on the role of experience and knowledge mobilisation, networks and opportunity recognition in developing migrant entrepreneurship and diverse contexts. By engaging with discussions on diversity in societies and by considering migrant entrepreneurship beyond the ethnic lenses, these chapters expand our understanding of contextual embedding of migrant entrepreneurs and entrepreneurial activities more generally.

Firstly, Joniada Barjaba explores the phenomenon of transnational entrepreneurship by looking at Albanian migrants doing business with Albania and Albanian returnees pursuing business activities with their former destination countries. Set within a context of limited entrepreneurship exposure during socialism in Albania, she emphasises the role of the migration experience in building knowledge, mobilising resources and developing networks across borders. This type of migration experience has a number of positive socio-economic benefits at the individual, community and country levels.

Secondly, the contribution from Alia Noor provides a critical examination of the under-explored notion of symbolic capital, underscoring how transnational migrants 
utilise this form of capital to facilitate their entrepreneurial endeavours and also from a policy perspective how they integrate into the host society. The chapter outlines the findings of a qualitative research study, based on interviews with a series of entrepreneurs using business accelerators for their new ventures, concluding how the symbolic capital they gain through the use of time they spend in the accelerator in time converts into economic value for the migrant entrepreneurs.

Thirdly, Xiping Shinnie and her co-authors' chapter focusses on the transnational nature of the opportunity structure, utilising the concept of multicultural hybridism to identify various breakout strategies of migrant entrepreneurs. Using data collected through interviews with Chinese entrepreneurs in an ethnic diverse city in the UK, she highlights their breakouts in other than ethnic markets, to include the host and home country mainstream markets. The chapter aims to emphasise the super-diverse entrepreneurial spaces migrants can tap into that support both economic growth and social integration.

Fourthly, we have included a study of Michał Borkowski and co-authors, which reveals the critical importance of diaspora networks in immigrant business foundation by using Poland as an empirical setting of a new and rapidly developing immigrant destination in the EU. In a country which has been for decades - due to unfortunate historical events - almost 'monoethnic', a rapid expansion of the immigrant community, dominated by Ukrainians is a novel phenomenon. Yet, Ukrainians who are Polish neighbours are quite close in terms of cultural traits, customs to a receiving society. The authors posit that the wider interdiasporic linkages within the migrant community originating from former Soviet countries is an important asset in business creation and development.

Fifthly, we present a study of Héctor José Martínez Arboleya, which focusses on Mexican entrepreneurial activities in the Québec region in Canada. Whilst studies on Mexican immigrants are numerous, the economic analyses of integration processes of this ethnic group are dominated by labour market insertion, occupational mismatch and upward mobility processes. Yet, the analysis of entrepreneurial activities of Mexican immigrants, especially beyond the US economy, is scarce. The qualitative study conducted in three cities: Montréal, Québec and Gatineau unveils surprisingly weak support from ethnic institutions and networks when it comes to business creation and further development.

In the final chapter of this volume, Sakura Yamamura and Paul Lassalle examine the notion of diversity, arguing that this is an increasingly important conceptual lens through which to explore the linkages between entrepreneurship and migration. In this epilogue, the authors identify four different dimensions of diversity and diversification which impact on experiences of migrant entrepreneurs and argue that these diversities are inherently embedded within the context of a super-diversified society in which migrant entrepreneurs negotiate their existence and struggle to establish their business ventures. By presenting migrant entrepreneurship through a diversity and diversification perspective, the authors contribute not only to the debates relating to the linkages between entrepreneurship and migration but also no less important wider scholarly debates on the notion of superdiversity within contemporary societies. 
This book offers a safe space to critically examine the specific social, cultural and political contexts of excluded groups of migrants (old and new arrivals: legal, illegal and refugees) and develop a much-needed theoretical and policy-related set of writings that can cast light on the workings and complexities of processes of global migration and how entrepreneurship can act as an engine to drive forward social integration as well as alleviate growth. By presenting migrant entrepreneurship through diverse perspectives, this book calls for a more explicit consideration of the nexus between entrepreneurship and migration (and indeed, migrant-led diversification of societies) and paves a way for new groups to be considered and for new theories to be developed in migrant entrepreneurship research.

\section{REFERENCES}

Aldrich, H. E., \& Waldinger, R. (1990). Ethnicity and entrepreneurship. Annual Review of Sociology, 16, 111-135.

Anderson, A. R., Dodd, S. D., \& Jack, S. (2010). Network practices and entrepreneurial growth. Scandinavian Journal of Management, 26(2), 121-133.

Anthias, F. (2002). Where do I belong? Narrating collective identity and translocational positionality. Ethnicities, 2(4), 491-514.

Bruton, G. D., Ahlstrom, D., \& Li, H. L. (2010). Institutional theory and entrepreneurship: Where are we now and where do we need to move in the future?. Entrepreneurship Theory and Practice, 34(3), 421-440.

Brzozowski, J., \& Cucculelli, M. (2020). Transnational ties and performance of immigrant firms: Evidence from Central Italy. International Journal of Entrepreneurial Behavior \& Research, 26(8), 1787-1806.

Brzozowski, J., Cucculelli, M., \& Surdej, A. (2017). The determinants of transnational entrepreneurship and transnational ties' dynamics among immigrant entrepreneurs in ICT sector in Italy. International Migration, 55(3), 105-125.

Burns, P. (2001). Entrepreneurship and small business. Basingstoke: Palgrave.

Down, S. (2013). The distinctiveness of the European tradition in entrepreneurship research. Entrepreneurship and Regional Development, 25(1-2), 1-4. https://doi.org/10.1080/08985626. 2012.746876

Drori, I., Honig, B., \& Wright, M. (2009). Transnational entrepreneurship: An emergent field of study. Entrepreneurship Theory and Practice, 33(5), 1001-1022.

Edwards, P., Ram, M., Jones, T., \& Doldor, S. (2016). New migrant businesses and their workers: Developing, but not transforming, the ethnic economy. Ethnic and Racial Studies, 39(9), 1587-1617.

Gartner, W. B. (2013). Creating a community of difference in entrepreneurship scholarship. Entrepreneurship \& Regional Development, 25(1-2), 5-15.

Giddens, A. (1984). The constitution of society: Outline of the theory of structuration. Berkeley, CA: University of California Press.

Imas, J. M., Wilson, N., \& Weston, A. (2012). Barefoot entrepreneurs. Organization, 19(5), 563-585.

Johannisson, B. (2011). Towards a practice theory of entrepreneuring. Small Business Economics, 36(2), 135-150.

Kloosterman, R. C., Rusinovic, K., \& Yeboah, D. (2016). Super-diverse migrants-Similar trajectories? Ghanaian entrepreneurship in the Netherlands seen from a mixed embeddedness perspective. Journal of Ethnic and Migration Studies, 42(6), 913-932.

Koning, J., \& Verver, M. (2013). Historicizing the 'ethnic' in ethnic entrepreneurship: The case of the ethnic Chinese in Bangkok. Entrepreneurship \& Regional Development, 25(5-6), 325-348.

Lassalle, P., \& Scott, J. M. (2018). Breaking-out? A reconceptualisation of the business development process through diversification: The case of polish new migrant entrepreneurs in Glasgow. Journal of Ethnic and Migration Studies, 44(15), 2524-2543. 
Lassalle, P., \& Shaw, E. (2021). Trailing wives and constrained agency among women migrant entrepreneurs: An intersectional perspective. Entrepreneurship Theory and Practice, 0(0), 1-26. https://doi.org/10.1177/1042258721990331

McKeever, E., Anderson, A., \& Jack, S. (2014). Entrepreneurship and mutuality: Social capital in processes and practices. Entrepreneurship \& Regional Development, 26(5-6), 453-477.

Portes, A., Guarnizo, L. E., \& Haller, W. J. (2002). Transnational entrepreneurs: An alternative form of immigrant economic adaptation. American Sociological Review, 67(2), 278-298.

Ram, M., Jones, T., \& Villares-Varela, M. (2016). Migrant entrepreneurship: Reflections on research and practice. International Small Business Journal, 35(1), 3-18. https://doi. org/10.1177/0266242616678051.

Ram, M., Theodorakopoulos, N., \& Jones, T. (2008). Forms of capital, mixed embeddedness and Somali enterprise. Work, Employment and Society, 22(3), 427-446.

Rath, J., \& Kloosterman, R. (2000). “Outsiders' business: A critical review of research on immigrant entrepreneurship. International Migration Review, 34(3), 657-681.

Rehn, A., \& Taalas, S. (2004). Znakomstva I Svyazi! [Acquaintances and connections]: Blat, the Soviet Union and mundane entrepreneurship. Entrepreneurship and Regional Development, 16(3), 235-250.

Rodgers, P., Vershinina, N., Williams, C. C., \& Theodorakopoulos, N. (2019). Leveraging symbolic capital: The use of blat networks across transnational spaces. Global Networks, 19(1), 119-136.

Syrett, S., \& Sepulveda, L. (2011). Realising the diversity dividend: Population diversity and urban economic development. Environment and Planning A: Economy and Space, 43(2), 487-504.

Vershinina, N., Rodgers, P., McAdam, M., \& Clinton, E. (2019). Transnational migrant entrepreneurship, gender and family business. Global Networks, 19(2), 238-260.

Vershinina, N., Rodgers, P., Tarba, S., Khan, Z., \& Stokes, P. (2020). Gaining legitimacy through proactive stakeholder management: The experiences of high-tech women entrepreneurs in Russia. Journal of Business Research, 119, 111-121.

Vertovec, S. (2007). Super-diversity and its implications. Ethnic and Racial Studies, 30(6), 1024-1054.

Villares-Varela, M., \& Essers, C. (2019). Women in the migrant economy. A positional approach to contextualize gendered transnational trajectories. Entrepreneurship \& Regional Development, $31(3-4), 213-225$.

Watson, T. J. (2013). Entrepreneurship in action: Bringing together the individual, organizational and institutional dimensions of entrepreneurial action. Entrepreneurship \& Regional Development, 25(5-6), $404-422$.

Welter, F., \& Smallbone, D. (2006). Exploring the role of trust in entrepreneurial activity. Entrepreneurship Theory and Practice, 30(4), 465-475.

Welter, F., Baker, T., Audretsch, D. B., \& Gartner, W. B. (2017). Everyday entrepreneurship —A call for entrepreneurship research to embrace entrepreneurial diversity. Entrepreneurship Theory and Practice, 41(3), 311-321. https://doi.org/10.1111\%2Fetap.12258

Wilson, K. L., \& Portes, A. (1980). Immigrant enclaves: An analysis of the labor market experiences of Cubans in Miami. American Journal of Sociology, 86(2), 295.

Yamamura, S., \& Lassalle, P. (2019). Approximating entrepreneurial superdiversity: Reconceptualizing the superdiversity debate in ethnic minority entrepreneurship. Journal of Ethnic and Migration Studies, 46(11), 1-22.

Zhou, M. (2004) Revisiting ethnic entrepreneurship: Convergencies, controversies, and conceptual advancements. International Migration Review, 38(3), 1040-1074. 
This page intentionally left blank 